\title{
Modeling the regional agro-elite's social position in rural areas' sustainable development system
}

\author{
Tamara Bulygina ${ }^{1}$, Evgeniy Tufanov ${ }^{2}$, Sergei Yanush $^{2}$, Inna Kravchenko ${ }^{2}$ and Valentine \\ Ivashova $^{2, *}$ \\ ${ }^{1}$ North Caucasus Federal University, 1, Pushkin Street, 355017, Stavropol, Russia \\ ${ }^{2}$ Stavropol State Agrarian Univiversity, 12, Zootechnicheskiy Lane, 355017, Stavropol, Russia
}

\begin{abstract}
The article concretizes the social position of the regional agrarian elite in the system of sustainable development of rural areas on the basis of factor analysis carried out by the method of principal components. A survey of 73 leaders and chief specialists of successful agricultural organizations in the South of Russia, traditionally represented by rural areas, was carried out in October-November, 2020 using Google Forms. The data was processed in SPSS Statistics (version 21) and used the Sustainable Development Goals proclaimed by the UN in 2015 as the 2030 Agenda for Sustainable Development. Seventeen Sustainable Development Goals were assessed on a five-point scale of significance in terms of relevance for agricultural organizations in rural areas of southern Russia. The assessments show the social position of the regional agrarian elite regarding the goal-setting in the field of sustainable development, both in rural areas and agricultural organizations. Factor analysis was carried out by the method of separation of the main components with Varimax Rotation with Kaiser Normalization. We present the models of the regional agrarian elite's social position in the system of sustainable development of territories.
\end{abstract}

\section{Introduction}

Understanding the social position of elite groups in society is relevant in connection with the powers and the possibilities of their influence on various spheres of life. Sociological interpretation of the key concept of the research - "social position", involves two interrelated and complementary aspects. Social position is the position of an individual or group in the system of relations in society. In addition, social position can be seen as the views, ideas, attitudes and dispositions of the individual and the group regarding the conditions of their own life, implemented and defended in the reference groups.

Based on numerous theoretical approaches to the "elite" category, we can give its following generalizing definition: the elite are social groups that occupy the highest positions in society, possessing the maximum degree of power and the ability to influence

\footnotetext{
*Corresponding author: vivashov@mail.ru
} 
society. Since the "elite" groups differ in many ways, it is possible to classify the elites. First of all, elites can be subdivided according to their functional characteristics. Accordingly, the following are distinguished: political, economic and culturalinformational elites.

The regional agrarian elite can be classified as economic elite, the localization of which is determined by territorial division. The most significant influence of the regional agrarian elite on the power processes in the region is expected in territories with favorable natural and climatic conditions and a high share of agricultural production.

The processes of institutionalization of the agrarian elite can be viewed in several dimensions. The agrarian elite are represented by a complex unity of factors that ensure its existence: professional meritocratic and societal hierarchical.

The professional-meritocratic factor is a condition for the allocation of not only highly professional representatives of the agrarian specialty, but also people with managerial and leadership qualities to the management structures of agro-industrial enterprises. It is formation of a kind of agrarian establishment in the regional professional community.

The societal-hierarchical factor is characterized by the determination of a specific social group. The regional agrarian elite are characterized by an active public position, interaction with state and municipal authorities to provide support for professional and economic processes in the agricultural sector. In addition, at the regional level, we are seeing a movement towards self-reproduction and upholding positions of power, including through clannishness.

The mechanisms of institutionalization of the agrarian elite are currently insufficiently studied. In the domestic social science literature in the published works of A.S. Bystrova, A.B. Daugavet, A.V. Duki, N.V. Kolesnik, A.V. Nevsky, D.B. Tev we see the ideas about the characteristics of the process of institutionalization of the political elite, which are most intensive during the period of active societal changes.

According to the results of sociological studies of elites conducted in Russia over the past 3-5 years, respondents note that education is important not in itself, but as an important social resource for building a professional career.

In the context of the global Agenda for Sustainable Development, an urgent question arises - what is the social position of the regional agrarian elite in the system of sustainable development of rural areas in the South of Russia. The mathematical tools for modeling the social position of the regional agrarian elite are used as the main methodological approach.

\section{Methods}

To model the social position of the regional agrarian elite in the system of sustainable development of rural areas, a survey was conducted among the leaders and chief specialists of successful agricultural organizations in the South of Russia (traditionally represented by rural areas). A total of 73 people took part in it. The survey was conducted in OctoberNovember, 2020 using Google Forms. Data was processed with SPSS Statistics (version 21).

The questionnaire uses the Sustainable Development Goals proclaimed by the UN in 2015 as the 2030 Agenda for Sustainable Development. Seventeen sustainable development goals were assessed on a five-point scale for their relevance for agricultural organizations in rural areas of southern Russia. The assessments show the social position of the regional agrarian elite regarding the goal-setting in the field of sustainable development, both in rural areas and agricultural organizations. Factor analysis was carried out by the method of separation of the main components with Varimax Rotation with Kaiser Normalization. It 
presents the models of the social position of the regional agrarian elite in the system of sustainable development of territories.

\section{Results}

The full explained variance for the expert category from the regional agrarian elite is $80.2 \%$ and is determined by 5 components. Data is presented in Table 1.

Table 1. Full explained variance of SDG assessments by experts from the regional agrarian elite.

\begin{tabular}{|c|c|c|c|c|c|c|c|c|c|}
\hline \multirow[b]{2}{*}{ 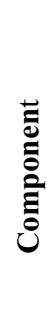 } & \multicolumn{3}{|c|}{ Initial eigenvalues } & \multicolumn{3}{|c|}{$\begin{array}{c}\text { Sums of squares of } \\
\text { extraction loads }\end{array}$} & \multicolumn{3}{|c|}{$\begin{array}{c}\text { Sums of squares of } \\
\text { rotational loads }\end{array}$} \\
\hline & $\stackrel{\bar{\pi}}{0}$ & 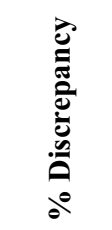 & 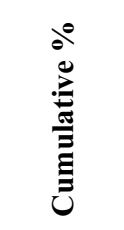 & 营 & 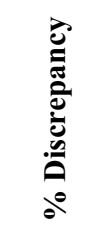 & 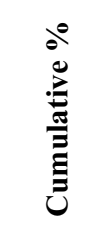 & है & 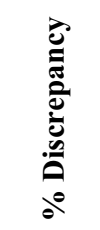 & 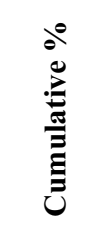 \\
\hline 1 & 6.168 & 36.283 & 36.283 & 6.168 & 36.283 & 36.283 & 3.335 & 19.617 & 19.617 \\
\hline 2 & 2.592 & 15.247 & 51.529 & 2.592 & 15.247 & 51.529 & 2.963 & 17.430 & 37.048 \\
\hline 3 & 2.000 & 11.765 & 63.294 & 2.000 & 11.765 & 63.294 & 2.831 & 16.651 & 53.699 \\
\hline 4 & 1.478 & 8.693 & 71.988 & 1.478 & 8.693 & 71.988 & 2.506 & 14.742 & 68.441 \\
\hline 5 & 1.400 & 8.233 & 80.221 & 1.400 & 8.233 & 80.221 & 2.003 & 11.780 & 80.221 \\
\hline 6 & 0.821 & 4.831 & 85.051 & & & & & & \\
\hline 7 & 0.699 & 4.111 & 89.162 & & & & & & \\
\hline 8 & 0.618 & 3.637 & 92.799 & & & & & & \\
\hline 9 & 0.355 & 2.091 & 94.890 & & & & & & \\
\hline 10 & 0.283 & 1.663 & 96.553 & & & & & & \\
\hline 11 & 0.208 & 1.226 & 97.779 & & & & & & \\
\hline 12 & 0.162 & 0.951 & 98.730 & & & & & & \\
\hline 13 & 0.096 & 0.563 & 99.294 & & & & & & \\
\hline 14 & 0.056 & 0.330 & 99.624 & & & & & & \\
\hline 15 & 0.046 & 0.273 & 99.896 & & & & & & \\
\hline 16 & 0.015 & 0.086 & 99.982 & & & & & & \\
\hline 17 & 0.003 & 0.018 & 100.000 & & & & & & \\
\hline
\end{tabular}

We listed 17 SDGs, the significance of which was assessed in the course of an expert survey, as a result of factor analysis performed by Rotation Method: Varimax with Kaiser Normalization (Rotation converged in 11 iterations). All 17 SDGs were grouped into 5 factors of sustainable development of territories in the views of the regional agrarian elite from among the leaders and chief specialists of successful agricultural enterprises of the Stavropol Territory.

The listed 17 sustainable development goals for experts from among the regional agrarian elite were grouped into 5 factors as a result of the factor analysis performed by the Rotation Method: Varimax with Kaiser Normalization (Rotation converged in 11 iterations). 
Table 2. Rotated component matrix for experts from the regional agrarian elite.

\begin{tabular}{|c|c|c|c|c|c|}
\hline \multirow{2}{*}{ Name of SDGs } & \multicolumn{5}{|c|}{ Component } \\
\hline & 1 & 2 & 3 & 4 & 5 \\
\hline SDG 1. End poverty in all its forms & 0.857 & -0.101 & 0.062 & 0.051 & 0.052 \\
\hline SDG 2. Improve feeding of the population & 0.843 & 0.087 & 0.120 & 0.262 & 0.007 \\
\hline SDG 3. Healthy lifestyle & 0.065 & -0.114 & 0.367 & 0.841 & 0.175 \\
\hline $\begin{array}{l}\text { SDG 4. Education of high quality } \\
\text { throughout life }\end{array}$ & 0.182 & 0.039 & -0.066 & 0.880 & 0.255 \\
\hline SDG 5. Gender equality & 0.153 & -0.073 & -0.023 & -0.142 & -0.874 \\
\hline $\begin{array}{l}\text { SDG 6. Sustainable water management and } \\
\text { sanitation }\end{array}$ & -0.369 & -0.099 & 0.532 & 0.502 & -0.276 \\
\hline SDG 7. Accessible to all sources of energy & 0.396 & 0.390 & 0.188 & 0.327 & 0.602 \\
\hline \begin{tabular}{|l}
$\begin{array}{l}\text { SDG 8. Economic growth and full } \\
\text { employment }\end{array}$ \\
\end{tabular} & 0.329 & -0.057 & 0.506 & 0.467 & 0.335 \\
\hline $\begin{array}{l}\text { SDG 9. Development of productive } \\
\text { infrastructure for industrialization and } \\
\text { innovation }\end{array}$ & 0.245 & 0.735 & 0.284 & 0.097 & 0.047 \\
\hline $\begin{array}{l}\text { SDG 10: Reduce inequality within and } \\
\text { between countries }\end{array}$ & 0.064 & 0.403 & 0.818 & 0.045 & 0.168 \\
\hline $\begin{array}{l}\text { SDG 11. Make cities and human } \\
\text { settlements inclusive, safe, resilient }\end{array}$ & 0.310 & 0.107 & 0.630 & 0.231 & 0.608 \\
\hline $\begin{array}{l}\text { SDG 12. Ensure sustainable consumption } \\
\text { and production patterns }\end{array}$ & 0.461 & 0.148 & 0.819 & 0.113 & 0.026 \\
\hline SDG 13. Tackling climate change & 0.517 & 0.428 & 0.415 & -0.092 & -0.192 \\
\hline $\begin{array}{l}\text { SDG 14. Sustainable use of marine } \\
\text { resources for sustainable development }\end{array}$ & -0.069 & 0.923 & 0.068 & -0.035 & 0.033 \\
\hline $\begin{array}{l}\text { SDG 15. Protect and restore terrestrial } \\
\text { ecosystems, including combating } \\
\text { desertification, land degradation and } \\
\text { biodiversity loss }\end{array}$ & 0.046 & 0.752 & 0.070 & -0.126 & 0.218 \\
\hline $\begin{array}{l}\text { SDG 16. Peaceful and inclusive societies } \\
\text { for sustainable development }\end{array}$ & 0.433 & 0.563 & -0.125 & 0.502 & -0.318 \\
\hline $\begin{array}{l}\text { SDG } 17 \text { Sustainable development through } \\
\text { global partnerships }\end{array}$ & 0.771 & 0.323 & 0.287 & 0.027 & 0.048 \\
\hline
\end{tabular}

According to the content of the grouped sustainable development goals, it can be said that the first factor is determined by a set of variables: SDG 1. Eradication of poverty in all its forms (load factor $\mathbf{0 . 8 5 7}$ ); SDG 2. Improve feeding of the population (load factor $\mathbf{0 . 8 4 3}$ ); SDG 17. Sustainable development through global partnerships (load factor $\mathbf{0 . 7 7 1}$ ); SDG 13. Tackling climate change (load factor $\mathbf{0 . 5 1 7}$ ). Thus, the first factor can be interpreted as achieving sustainable development through the alignment of resources in relation to the needs of territories and population.

The second factor is driven by a set of variables: SDG 14. Sustainable use of marine resources for sustainable development $(\mathbf{0 . 9 2 3})$; SDG 15. Protect and restore terrestrial ecosystems, including combating desertification, land degradation and biodiversity loss (0.752); SDG 9. Development of productive infrastructure for industrialization and 
innovation (0.735); SDG 16. Peaceful and inclusive societies for sustainable development (0.563). Thus, the second factor can be interpreted as achieving sustainable development through the conservation of aquatic, terrestrial and social ecosystems.

The third factor is determined by a set of variables: SDG 12. Ensure sustainable consumption and production patterns (0.819); SDG 10. Reduce inequality within and between countries (0.818); SDG 11. Make cities and human settlements inclusive, safe, resilient (0.630); SDG 6. Rational water use and sanitation (0.532); SDG 8. Economic growth and full employment (0.506). Thus, the third factor can be interpreted as achieving sustainable development through the rationality of all processes from production to consumption.

The fourth factor is determined by a set of variables: SDG 4. Education of high quality throughout life $\mathbf{( 0 . 8 8 0})$; SDG 3. Healthy lifestyle (0.841). Thus, the fourth factor can be interpreted as achieving sustainable development through the personal growth of everyone - education of high quality and a healthy lifestyle.

The fifth factor is determined by a set of variables: SDG 5. Gender equality (-0.834); SDG 7. Accessible to all sources of energy (0.602). Thus, the fifth factor can be interpreted as the priority of sustainable development is to respect the uniqueness of each person and provide available resources.

\section{Discussion}

Sustainable development of rural areas in the agrarian regions of the world is an urgent topic of socio-economic research. Modern information technology transformations affect the strategic management of the agricultural sector of the economy and raise the expectations of society regarding the level of social responsibility of decision-makers in the field of agricultural production and agricultural policy. Accordingly, understanding the social position of the regional agrarian elite in the system of sustainable development of rural areas is an important area of research.

The topic of the social position of the agrarian elite is relevant for modern China. Authors C. Zhou, Y. Liang, A. Fuller emphasize that the land issue has both a political and an academic aspect [1]. The decision on the possibility of transferring land to third parties has a number of important consequences. Previously, support for small farms had the effect of preserving and increasing land productivity, ensuring the safety of agricultural products at the expense of the responsibility of land users. The emerging opportunity to transfer land from peasants to outsiders opens up a movement to collect land, affecting millions of small farms. The land tenure restructuring process puts on the agenda the capitalization of agriculture, depriving peasants of land, proletarianization and the future land market in rural China. Here, not only the official policy of the authorities on the agrarian issue plays an important role, but also the social position of the leaders of agricultural production regarding the preservation of the quality indicators of agricultural land, the use of chemicals, the withdrawal of land from agricultural circulation, etc.

Lower wages in the agricultural sector are not unique to Russia alone. So in the publication of E. Wigton-Jones we see the statement that the share of workers with low wages is higher in rural municipalities than in urban [2]. The author notes the disinterest of the agrarian elite in the transition of the local economy to innovations in agriculture, which confirms the importance of the opinions and actions of this social group in determining the regional agricultural policy.

Authors B.M. McKay, G.D.L.T. Oliveira, J. Liu in their article raise controversial questions about a new political period for the development of agrarian relations [3]. The authors note that in the context of the crisis, the policies of neoliberal globalization are 
gaining strength in nationalist-populist and authoritarian movements, which makes a topical agenda the interaction of the land, agro-industrial and political elite. The position of the political and economic elite influences the pace of technological transformations in agricultural production. Thus, the study of the social position of the regional agrarian elite provides a useful basis for understanding the agrarian transformation in the modern period.

To reduce socio-economic imbalances between rural areas and areas with developed industry, institutional mechanisms are important to ensure their integration and support the agricultural sector. Researcher E. Waeterloos, using the example of state agrarian reform in South Africa, shows how inconsistency in the provision of public goods at the local level creates growing evidence of corruption, a struggle for power of local elites. The author draws conclusions based on the use of qualitative research methods, which is important for understanding the essence of the issue [4]. The application of the quantitative methods that were implemented in our study ensures the consistency of conclusions and their structuring in relation to certain models of the social position of the regional agrarian elite in the South of Russia. This, in our opinion, is the advantage of the performed factor analysis.

According to the author K. Narizny during the period of the rise of agrarian capitalism, the agrarian economic elite are developing, which is interested in a political system that guarantees equal rights for all in the eyes of the law. This is extremely important for the legitimacy of state power and increases the opportunities for the consolidation of the forces of the developing economy [5].

Comprehensive reform of agrarian relations actualizes the land management agenda. Researchers A. NyenyeziBisoka, A. Ansoms in their article note that during the reform in the 2000s in Rwanda, it became possible to acquire land, which led to its seizure by local elites [6]. According to the authors, the lack of strict regulation of land ownership issues leads to negative consequences: the emergence of large landowners and the exploitation of peasants. In general, ill-considered land reforms lead to an exacerbation of social contradictions and do not contribute to the sustainable development of rural areas $[7,8,9$, $10,11]$. In this study, we note the social immaturity of the position of the local elite in the development of agrarian relations. Similar examples can be traced in a number of other publications $[12,13,14,15]$ and provide an opportunity to understand what constitutes land inequality and the concentration of power in the agri-food system [16, 17, 18, 19]. For the system of sustainable development of rural areas, the social position of the regional and local agrarian elites and state authorities plays an important role. In general, according to the review of publications, it is determined a negative trend of disinterest of the agrarian elite in the social well-being of rural areas [20, 21, 22, 23, 24].

\section{Conclusion}

Thus, the conducted empirical research shows the social position of the regional agrarian elite regarding goal-setting in the field of sustainable development, which is described by 5 models:

- achieving sustainable development through the alignment of resources in relation to the needs of territories and population;

- achieving sustainable development through the preservation of aquatic, terrestrial and social ecosystems;

- achieving sustainable development through the rationality of all processes from production to consumption:

- achieving sustainable development through the personal growth of everyone education of high quality and a healthy lifestyle; 
- the priority of sustainable development is to respect the uniqueness of each person and provide available resources.

The use of mathematical models in determining the social position of certain groups of society, including the example of the regional agrarian elite, provides important information for reflection and systemic conclusions.

\section{References}

1. C. Zhou, Y. Liang, A. Fuller, Land 10(1)-58, 1-16 (2021)

2. E. Wigton-Jones, Journal of Economic Growth 25(4), 455-501 (2020)

3. B.M. McKay, G.D.L.T. Oliveira, J. Liu, Canadian Journal of Development Studies 41(3), 347-362 (2020)

4. E. Waeterloos, Canadian Journal of Development Studies 41(3), 399-416 (2020)

5. K. Narizny, Perspectives on Politics 18(2), 454-469 (2020)

6. A. Nyenyezi Bisoka, A. Ansoms, Canadian Journal of Development Studies 41(2), 243-259 (2020)

7. M.C.A. Wegerif, A. Guereña, Land 9(4), 101 (2020)

8. C. Yiyuan, Journal of Agrarian Change 20(2), 238-254 (2020)

9. N.G. Ali, Journal of Agrarian Change 20(2), 270-288 (2020)

10. G. Mapes, Context and Media 34, 100328 (2020)

11. K.M. Woods, World Development 127, 104780 (2020)

12. Haryan to Boundary Crossers: The transformation of civil society elites in Indonesia's post-authoritarian era, Politics and Governance 8(3), 120-129 (2020)

13. I.G. Surata, N.N. Mariadi, I.G.A.W. Sena, Journal of Critical Reviews 7(8), 972-976 (2020)

14. L.A. Lanzona, Millennial Asia, 10(3), 272-298 (2019)

15. L.C. Gwiriri, J. Bennett, C. Mapiye, S. Burbi, Development and Change, 50(6), 16641686 (2019)

16. C.M.Y. Park, Feminist Economics, 25(4), 21-44 (2019)

17. S. Balakrishnan, International Journal of Urban and Regional Research 43(4), 617-632 (2019)

18. S. Sauer, Latin American Perspectives 46(4), 103-121 (2019)

19. M.A. Jan, New Perspectives on Pakistan's Political Economy: State, Class and Social Change, 176-198 (2019)

20. O.A. Altaeva, E.G. Imeskenova, O.M. Chibikova, IOP Conference Series: Earth and Environmental Science 395(1), 012006 (2019)

21. V.N. Goncharov, A.M. Erokhin, V.A. Ivashova, L.A. Tronina, O.N. Kamalova, IOP Conference Series: Earth and Environmental Science 422(1), 012124 (2020)

22. V.A. Ivashova, T.N. Dukhina, S.I. Tarasova, E.N. Kalugina, E.V. Taranova, Life Science Journal 11(9), 326-329 (2014)

23. B. Poulsen, H. Vogt, J.V. Sigurosson, Nordic Elites in Transformation, 1050-1250 (2019)

24. M. López, States, Elites, and Inequality in Latin America Sociology Compass 12(8), e12598 (2018) 